\title{
Horizontal Europeanisation
} The Transnationalisation of Daily Life and Social Fields in Europe

\section{Edited by Martin Heidenreich}

\section{A European field of public administration?}

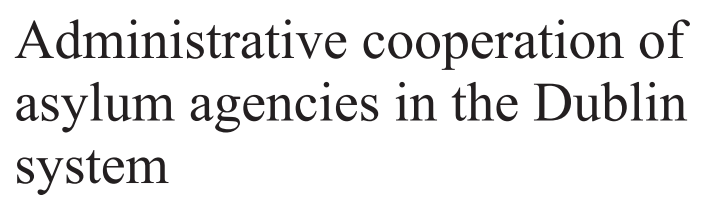

Christian Lahusen and Marius Wacker

(CC BY-NC-ND 4.0)

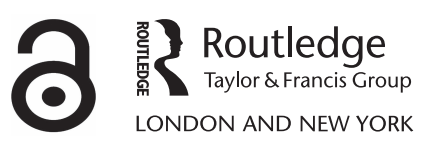





\title{
8 A European field of public administration?
}

\author{
Administrative cooperation of \\ asylum agencies in the Dublin \\ system
}

\section{Christian Lahusen and Marius Wacker}

\subsection{Introduction}

The European Union started to coordinate and harmonise the asylum policies of their Member States in 1999 within a common 'area of freedom, security and justice', as stipulated by the Treaty of Amsterdam. However, the communitarisation of asylum policies by the EU has not met its main targets, despite the installation of the Common European Asylum System (CEAS) and several attempts to implement and improve these regulations and directives by means of legislative reforms, political programmes and administrative initiatives. Today, we are still far from a European-wide asylum regime that implements harmonised procedures, and grants equivalent protection titles across all Member States (Council of the European Union, 2016a). National asylum systems and recognition rates continue to differ widely within the EU (AIDA, 2017; EASO, 2017a).

Nevertheless, the CEAS has brought important changes to the work of public authorities in all Member States. In fact, asylum agencies throughout Europe were incorporated into a transnational division of administrative labour, following the idea that Member States should cooperate in the handling of asylum applications. A number of EU regulations and directives have been issued since the 1990s with this aim, thus giving birth to the so-called Dublin system. In vigour since 1997, it has created an administrative 'Dublin space', which consists of the 28 EU Member States plus Iceland, Norway, Lichtenstein and Switzerland (EU+ countries). It has introduced a 'Dublin procedure' geared to identify the Member State responsible for processing each individual asylum application of those persons already in the Dublin space. For this purpose, asylum agencies from all Member States are compelled to apply a fixed hierarchy of criterion as foreseen in the respective EU Dublin Regulations, among them the criterion of 'country of first entry' into the Dublin space.

The Dublin procedure has had a considerable impact on the administrative work of asylum agencies across the EU+, because it involves various tasks (information exchange, allocation of responsibility, case management, record keeping, transfers of applicants) and calls for repeated contacts and exchanges between case officers of national agencies on a daily basis. This enforced cooperation 
adds complexity to the work of asylum agencies, but also provides them with an option to examine and delegate the responsibility of individual cases to other Member States. Dublin thus enforces a system of mutual exchanges and working relations. It has created a European administrative field (Lahusen, 2016) with an interdependent, albeit asymmetric, division of labour. In fact, within the Dublin system, the 'balance of services' of each national agency is strongly impacted by the performance of the other Member State bureaucracies (Bast, 2007).

We thus propose to analyse the Dublin system as a transnational bureaucratic field. Our research aim is to better understand the way how this bureaucratic field is structured and how it operates within the regulatory framework of the CEAS. More specifically, we wish to unveil the patterns of transnational cooperation between public authorities across time. In particular, we are interested in the division of labour of this Dublin system, and the implicit challenges and conflicts it is exposed to. Overall, we aim to identify the bureaucratic rationale behind the Dublin system.

The relevance of this 'asylum community' (Bast, 2007) is not necessarily based on the amount of cases it processes. In fact, transnational cooperation between asylum agencies within the Dublin system is ultimately only effective in a smaller number of asylum applications. In the period from 2010 to 2014, for instance, only $10 \%$ of all registered applicants were Dublin-related cases (with around 62,000 Dublin requests p.a. in the same period), whereof only $2 \%$ resulted in factual Dublin transfers (EASO, 2016a). The relevance of the Dublin procedure does not reside in the number of cases it processes. Its significance rather stems from the lessons it allows us to draw about the bureaucratic construction of Europe in terms of cross-national administrative labour, and the horizontal Europeanisation of public authorities it entails. ${ }^{1}$

The 'bureaucratic field' merits closer inspection also because we know very little about the administrative side of the Dublin system. So far, discourse in the mass media, in politics and science has focused on the political and legal side of the Dublin system (ECRE, 2016a, 2016b; Fratzke, 2015; Maas et al., 2015; Maiani, 2016). Since 2015, one gains the impression that EU migration and asylum policies have been exposed to a serious 'crisis induced' change, which has resulted in a weakening of the Common European Asylum System (Baumgartner et al., 2016; Chetail et al., 2016; European Commission, 2017a; Trauner, 2016). However, even if the Dublin system is exposed to political contentions, and even though the future of European coordination in terms of asylum is more than open, it is remarkable that it is still considered to be the 'cornerstone' of the CEAS (European Commission, 2016) and thus a vibrant example for influential transnational administrative cooperation (Council of the European Union, 2016b; European Commission, 2016, 2017b: 18; Hruschka, 2016).

This alleged persistence calls for a closer analysis of the Dublin system in its administrative dimension. In the following, we will thus centre on the cooperation and exchange relations between public administrations within the regulatory frame introduced by the Dublin Regulations. In a first step, we will make use of sociological field theory in order to argue on a conceptual level that the Dublin 
system has boosted transnational cooperation between Member State administrations, and thus contributed to the establishment of a European bureaucratic field with inherent challenges and contestations. In a second step, we will empirically validate our research assumptions by making use of Dublin data made available by Eurostat on Dublin requests and Dublin factual transfers. ${ }^{2}$ Our goal is to identify transnational interaction patterns between Member State agencies in order to highlight their spatial configurations in the course of time. Moreover, we will also investigate the outcomes of transnational cooperation in order to identify potential asymmetries concerning the number of Dublin requests and transfers.

\subsection{Conceptual framework}

Our analyses depart from a field-theoretical approach (see Chapter 2 in this volume; also Bourdieu, 1987, 1998). We argue that the regulatory framework of the CEAS has communitarised asylum policies and competencies, and has thus established a field of actors involved in administering the sovereign right of states to confer or deny asylum. It is our understanding that a field is constituted on the basis of common issues, actors, resources, rules and a shared sense of legitimacy. In the case of asylum administrations, we argue that the Dublin Regulations have been the core instrument employed to Europeanise the administrative field across Europe. Dublin has instituted a responsibility allocation mechanism that drags public authorities from all Member States into a joint space of shared responsibilities. In this sense, 'asylum' has become the common issue, and the provision or denial of asylum titles the 'public good' at stake. The Dublin system has helped to establish a bureaucratic field because it promotes the idea of legitimate rules and norms guiding the conduct of all administrative actors. In fact, administrative cooperation within the Dublin space is built on a set of highly formalised and standardised competencies, tasks and routines, and thus on the 'illusio' of impartial, orderly and verifiable procedures (Bourdieu, 1991: 70 f., 1997). Political and administrative stakeholders within this field invest considerable energy in generating and reproducing these bureaucratic rules and norms (Schneider and Nieswandt, 2018), because they stabilise the field and legitimise the shared activities and the field's mission.

An analysis of the Dublin system in field-theoretical terms sensitises us to the contentious nature of administrative cooperation. In fact, the communitarisation of asylum and the horizontal Europeanisation of administrative practices unleashed contentions between state actors, because policy decisions about the allocation of this public good materialised relations of power, and thus favoured some interests while marginalising others. While these contentions are primarily political, they do affect the bureaucratic field, because administrations have to do the legwork of implementing legislative decisions with their deficiencies, constraints and contradictions. In this sense, political contentions are more often than not translated into bureaucratic contentions. In the case of asylum, this is more than evident, because national administrations have to cooperate within a regulatory system that enforces a highly asymmetric division of labour and 'burden sharing' as we 
will show in more detail (e.g. countries of first entry of migrants at the external border of the Dublin space vs. target countries of migrants). Additionally, contentions are not always visible, but pervasive, because Dublin installs a system of shared responsibilities and interdependencies, where the action of one member may affect the actions of others.

These general reflections help to understand the basic rationale of bureaucratic fields. However, they paint an imprecise picture of the inherent challenges and contradictions of the Dublin system as a Europeanised administrative field. An accurate analysis has to start with the acknowledgement that administrative cooperation within the Dublin space struggles with the institutional architecture of the EU, namely with the fact that the EU can operate - in terms of administrative implementation - only through its Member States. This specificity considerably limits the power of the EU to enforce its own provisions and guarantee a strict harmonisation of administrative practices. Different recognition rates as well as dissimilar administrative standards and criteria between Member States remain in place, and challenge the EU institutions in their attempt to establish an orderly asylum system (AIDA, 2017; EASO, 2017a). What these indications show are the limits of a purely 'vertical' form of Europeanisation (Featherstone and Radaelli, 2003), which relies on the 'downloading' of public policies and administrative regulations. The establishment of a fully Europeanised bureaucratic field also requires a process of 'horizontal Europeanisation': public administrations have to be inserted into cross-national relations of cooperation, and their administrative routines and practices have to be reorganised accordingly. Referring to the conceptual framework of this book, we can highlight one mode of horizontal Europeanisation that seems to be of key importance: the establishment of shared norms and rules. In this sense, formalisation and standardisation is the preferred route of action in order to facilitate cross-national cooperation routines and a transversal recalibration of administrative routines (Lahusen, 2016). Other modes of Europeanisation are present too (e.g. political bargains and cross-national discourses and learning), but cannot be validated in this paper, due to limitations of the data.

The CEAS follows this approach by introducing at least three types of norms and rules. First, the CEAS has adopted the EU-specific 'minimalist' strategy of mutual recognition: Given the fact that Member States mutually recognise the asylum decisions taken by their national administrations, the communitarisation is limited to the question of how to allocate responsibilities for each asylum application. This minimalist strategy allows for a division of administrative labour, because national agencies that were formerly working exclusively within a national framework are now accepting each other's practices as complementary contributions to a common mission. Second, the CEAS establishes, identifies and allocates responsibilities. Administrations from 32 states are required to accept their responsibilities and to cooperate among each other in order to guarantee the function of the Dublin system. In this regard, the Dublin system has established a clear norm: It is the only component of the CEAS that claims to be a genuine 'common' and 'European' operating system (Wagner, 2018). In fact, the Dublin Regulations have established obligatory cooperation - which has become a 
'transnational administrative fact' (Bast, 2007: 11). Finally, EU institutions and national governments have been geared to develop a number of administrative procedures, tools and mechanisms to try to encourage and facilitate cross-national cooperation. In this regard, we can point to three instruments: (a) highly formalised routines were inserted into the asylum procedures of the related agencies in all Member States in order to help them identify and allocate responsibilities for asylum cases between Member States; (b) databases and digital systems of information exchange with automatic translations were developed and made available in all offices and work-places (Eurodac, Dublinet etc.); and (c) relevant knowledge was canonised and disseminated, for instance, by means of training programmes such as the EASO-Training Curriculum (ETC) (Lahusen, 2016: 123) by the European Asylum Support Office (EASO). ${ }^{3}$

The horizontal Europeanisation of public administration by means of formalisation and standardisation, however, has its limits. The regulatory approach introduced by the CEAS cannot guarantee a full enforcement of its norms and rules, because public agencies responsible for asylum applicants are part of the various Member States' bureaucratic apparatus. The 'European bureaucratic field' thus requires some sort of voluntary commitment by its components. In fact, agencies might always consider deviating - in practice - from this mandatory cooperation, because the EU has established no clear sanctioning system and has only limited means to coax deviant agencies to cooperate. As we will see, practical cooperation within the framework of the Dublin system is far from being pervasive and comprehensive. With regard to the modes of horizontal Europeanisation discussed in this book, we thus can assume that two other approaches play a role in fuelling cross-national cooperation within the Dublin system: the provision of resources and incentives to the various agencies involved in case work, and the political background work of ministries and governments in negotiating 'burden-sharing' policies and measures. Additionally, the CEAS has also established cross-national platforms of deliberation and learning between administrations and their personnel. The empirical data used in our analysis will not allow us to identify their effects on the field, but they are a plausible framework to interpret empirical findings. ${ }^{4}$

These reflections suggest that the administrative cooperation installed by the Dublin system is not free of deficiencies, contradictions and conflicts. In spite of the regulatory instruments and tools introduced by the CEAS, it is to be expected that the reality of the Dublin system will fall short of legal expectations. Our guiding assumption is that the Dublin system has established a highly unbalanced division of labour between public authorities with a plainly unequal 'burden sharing' and workload. These asymmetries within the bureaucratic field are associated to contextual factors. In first instance, they have to do with the contingencies and uncertainties of asylum, given that Member States are unevenly exposed to forced migration and the transit routes, and people fleeing from war, prosecution and famine. However, the main driving force stems from the 'political legacy' of Dublin. In fact, the current system is a product of political bargaining that has instituted and materialised an asymmetrical 'burden-sharing' between European 
administrations. The history of the CEAS and the Dublin Regulations, in particular, is a history of political conflicts and contestations. This contentiousness is a direct reaction to a latent contradiction between the demand for 'solidarity' between Member States in terms of a 'fair burden sharing' of irregular migrants arriving in Europe on the one hand, and the pressures to discipline and penalise Member States 'responsible' for the entrance of these migrants into the Dublin Space on the other (Lorenz, 2015). Evidently, these conflicts have reappeared in the aftermath of the so-called refugee crisis of 2015/2016, but they have always been virulent in European debates about the specific application of the Dublin system. Following these observations, we can thus identify one of the main cleavages within the field of asylum administrations: 'Target countries' are insisting both on the 'improvement' of the asylum systems of the countries 'responsible' for the 'illegal' entry of 'irregular' migrants to avoid 'secondary movements' and assure effective border controls, while the countries on the external borders are calling for fairer distribution and increased support, financial, technical and personal, in handling the high number of applications they have to process (Angenendt and Parkes, 2010).

In spite of these political legacies, however, we need to put more emphasis on the bureaucratic realities. Following field theory, we argue that an adequate understanding of the challenges and conflicts within the CEAS calls for an analysis of the Dublin system as an administrative field, particularly because Dublin system was not conceived of as a 'burden-sharing' mechanism of European solidarity, but as a purely bureaucratic mechanism of responsibility allocation. In particular, the regulatory framework of the CEAS and its Dublin system tried to suppress political conflicts about 'burden-sharing' by delegating responsibilities for problemsolving to the public administrations. Under these circumstances, bureaucrats took charge of disaggregating the 'burden' and dividing the work among themselves. The fact that the Dublin system operates mainly on the basis of formalised standard procedures and via digital tools (electronical work and the communication platform DubliNet, standardised forms with automatic translations and text modules, etc.) shows an attempt to depersonalise and depoliticise the working relations between public authorities by means of bureaucratic formalisation and objectivation (Amelung, 2017).

In spite of these attempts, contentions prevail within the European administrative field, because public authorities are constantly confronted with the asymmetries of 'burden-sharing'. Countries on the external borders of the EU are located at the central migration routes, are thus formally in charge of the handling of many asylum applications, meaning that they are consequently confronted with a higher rate of Dublin requests and transfers. As a consequence, conflicts and contentions between Member States are ever present in the administrative field, even if not voiced overtly. Local authorities, for instance, 'wave through' these persons in transit countries and countries at the external border of the Dublin space with high influx (Baumgartner et al., 2016: 48-49). Fingerprinting protocol is lax for arriving applicants in the Dublin space (Jurado et al., 2016: 22), as in the case of Italy (Kasparek and Tsianos, 2015: 17). Administrations abstain from 
employing more staff especially in the Italian Dublin Unit, ${ }^{5}$ Member States have engaged in several legal disputes addressing national courts, the European Court of Human Rights and the Court of Justice of the EU, which have led to the suspension of transfer to certain Member States due to 'systematic flaws' in their asylum systems or the time-consuming need to obtain 'individual guarantees' in advance of a transfer (Baumgartner et al., 2016: 49-50; Jurado et al., 2016: 21-22).

Finally, these conflicts influence the daily practices and routines of the single Dublin Units, as well. Even though the Dublin procedure is a highly formalised standard procedure, it leaves some room for variation for the single authorities in the concrete cooperation and handling of Dublin cases with each other. Dublin seems to provide public authorities with an option to engage in an implicit strategy of externalising and relocating responsibilities. A transfer of cases might fail because it requires, for instance, evidence to prove the responsibility of a certain country with regard to certain criteria of the Dublin Regulations; because public authorities maintain poor communication relations or delay responses to received requests; because the time is too short for a prompt transfer of responsibilities, in particular during high influx; because authorities have problems agreeing on the exact time and date of the transfer, and because they often disagree about whether a transfer can be carried out due to the case's specific circumstances, namely, applicants with severe intellectual disability (ID) (Jurado et al., 2016: 24-60).

Overall, these indications illustrate that the bureaucratic field is confronted with a number of potential challenges, deficiencies and conflicts. All of them have more or less direct effects on the work of the public authorities and their Dublin Units, as well as on their ability to deal with their caseloads and to engage in cross-national cooperation within their daily work. Field theory helps us to unravel this complex situation, by distinguishing between politics and bureaucracy, and thus between different - albeit intersected - dynamics within both fields. Political conflicts about the CEAS impact on, but do not necessarily translate into bureaucratic contentions, because the latter operates on the basis of established regulations and procedures, and on bureaucratic beliefs about the necessity and ability of an orderly, impartial and systematic execution of problem handling, and thus of proper administrative discourse arenas and cross-national deliberations. ${ }^{6}$

Should we want to understand the administrative reality of the Dublin system, we thus need to turn our views away for a moment from the fierce political debates and conflicts, and devote ourselves to the daily routine work of streetlevel bureaucrats, in particular regarding the Dublin system specific contacts and exchanges with colleagues in other European countries. More specifically, we need to take a closer look at the traces their work leaves within the electronic system introduced by Dublin. In particular, we need to inquire into the data of Dublin requests and transfers, in order to better understand to what extent Dublin works in administrative terms, and with which imperfections and conflicts it is confronted.

Following these field-theoretical reflections, we have identified two research assumptions that await empirical validation. One the one hand, we assume that the 
Dublin system has established - through its regulations, procedures and administrative tools - a field of administrative cooperation that follows its own mode of operation and thus exhibits stability and continuity across time, despite its inherent asymmetries, contestations and conflicts. If our assumption is correct, we ought to be able to show empirically that agencies of the Member States are soundly and continuously connected and that working relations might even have intensified over the course of time. On the other hand, field theory assumes that the asymmetries, cleavages and latent conflicts, which were inscribed in the administrative operations, articulate themselves even in the bureaucratic rationale of the field. In empirical terms, they ought to be noticeable in terms of inequalities, imbalances and a differential effectivity. As a proxy, we propose using the gap between the number of Dublin requests and factual transfers. Agencies inquire whether a foreign agency is responsible for handling an asylum application, before arranging and 'booking' a transfer of the persons concerned. While the number of requests will always be bigger, we assume that a disproportionate gap between requests and transfers can be taken as a measure of the imperfections, contradictions and conflicts inherent in the field. We thus expect that the administrative performance of national asylum agencies concerning the assignment of applications inter alia the transferal of responsibility is determined by the structural position of this country within the European administrative field, and by the connections it maintains with other Member States' asylum agencies.

\subsection{Shared jurisdictions and cooperation networks in the Dublin system}

We move now to an empirical analysis of the working relationships between national administrations in the area of Dublin requests and transfers. ${ }^{7}$ The aim is to validate whether cross-national cooperation between EU Member States is a well-established reality, and to highlight the potential asymmetries of this administrative collaboration. For this purpose, we have used the data provided by Member States about their Dublin requests and transfers, and assembled through Eurostat. ${ }^{8}$ Eurostat's Dublin data has been rightly criticised over the past years (AIDA, 2015; ECRE, 2018; European Commission, 2015), but it provides significant information about the longitudinal patterns and interactions of the functioning of the Dublin system in its 'spatial' dimension. We have used statistical tools of social network analysis, because this method is able to visualise and validate the shape and structure of administrative relations of work. National administrations appear as nodes within the network, and Dublin requests are treated as contacts. Contacts do not only say whether administrations maintain working relations, but can be assessed also in regard to their intensity, i.e. the number of exchanged requests, as well as their direction. Network analysis provides statistical measures that assess the density of the cross-national collaboration and the patterns guiding the Dublin system in practice.

In the following, we will develop our empirical analysis in five steps. First, we will devote our attention to the structure of cooperation regarding Dublin 
requests, both in terms of the network's structure and its evolution across time. Second, we will do the same analysis with regard to Dublin transfers, in order to corroborate whether factual reallocations exhibit a different pattern to those dealing with requests. Third, we will disaggregate the network for the position and role of each country within the overall field of administrative cooperation. Fourth, we will show on which side European countries are, i.e. whether they send out more requests and transfers than they receive. This will give us a good impression of the (distribution of) workloads. Finally, we will compare the requests and transfers in order to gain a better understanding about potential implementation gaps and structural discrepancies with regard to the workload.

With respect to Dublin requests, Figure 8.1 provides an initial visual representation of cross-national collaboration for 2015. We see that most countries are in contact with each other through mutual requests. However, collaboration is not evenly distributed across the European space. Some countries maintain only weak working relations with other nation-states, and some countries are not in contact at all, while others are intensively exchanging Dublin requests.

This general pattern merits closer inspection. For this purpose, we refer to Table 8.1, which assembles various statistical measures identifying the internal

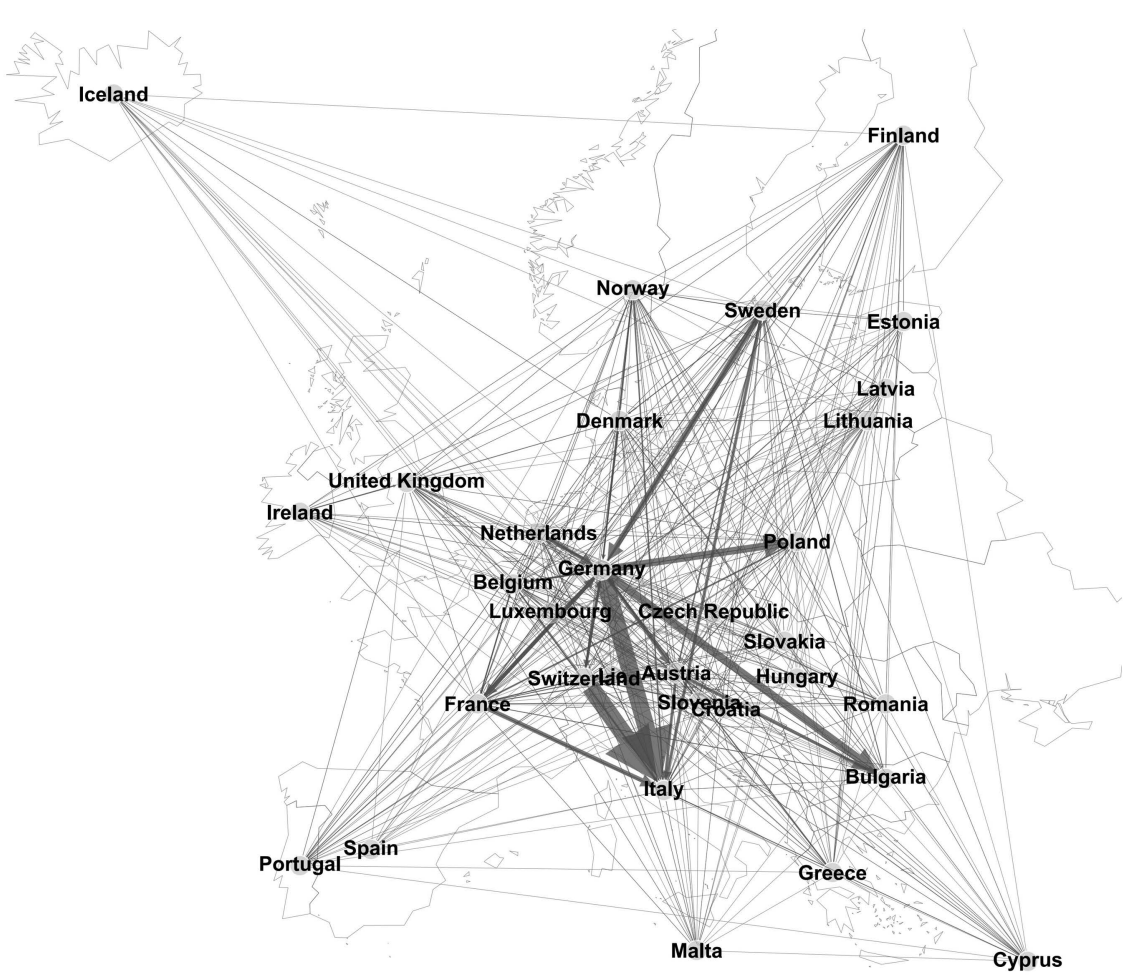

Figure 8.1 Dublin requests between EU Member States in 2015 (social network analysis) 
Table 8.1 Dublin requests: network structure 2008-2016

\begin{tabular}{|c|c|c|c|c|c|c|c|c|c|}
\hline Year & 2008 & 2009 & 2010 & 2011 & 2012 & 2013 & 2014 & 2015 & 2016 \\
\hline Number of edges & 461 & 577 & 563 & 599 & 575 & 553 & 548 & 589 & 584 \\
\hline $\begin{array}{l}\text { Average degree } \\
\text { (countries) }\end{array}$ & 28.8 & 36.1 & 35.2 & 37.4 & 35.9 & 34.6 & 34.3 & 36.8 & 36.5 \\
\hline $\begin{array}{l}\text { Average weighted } \\
\text { degree } \\
\text { (requests) }\end{array}$ & 659 & 1484 & 1354 & 1364 & 1537 & 2180 & 2437 & 2486 & 5832 \\
\hline Graph density & 0.465 & 0.582 & 0.568 & 0.604 & 0.580 & 0.557 & 0.552 & 0.594 & 0.589 \\
\hline $\begin{array}{l}\text { Connected } \\
\text { components }\end{array}$ & 3 & 3 & 3 & 3 & 2 & 1 & 1 & 1 & 1 \\
\hline
\end{tabular}

Source: Eurostat, own calculations.

structure of the field. Here we have assembled network coefficients for the entire period under analysis (2008 to 2016), all of which point in the same direction: We see that the Dublin system has established a rather integrated field of crossnational administrative cooperation. In fact, the network consists of 461 to 599 connections between the 32 countries. The density of the network is rather high, with coefficients ranging between 0.47 and 0.60 , thus showing that half of all potential pairs maintain collaborations. Additionally, we see that each country maintains exchanges with 29 to 37 other countries (i.e. on average with 18 countries, depending on whether one receives or sends requests). As regards the intensity of these working relations, the data indicate that each country exchanged on average 2,148 Dublin requests with other Member States per year.

If we look at the changes across time, we can highlight two striking findings. On the one hand, findings testify a strong continuity in terms of working relations between national administrations. On the other hand, we see that administrative cooperation increased between 2008 and 2016, and that this is mirrored in the growing density of the network's internal structure. A closer look at the findings clearly corroborated this interpretation. Thirty-two countries are part of the field, among them the 28 EU members and the four EFTA states Iceland, Lichtenstein, Norway and Switzerland. The average degree shows that the number of countries to which national administrations maintain contact ranges between 29 (in 2008) and 37 (in 2016). As this coefficient counts the sending and receiving nodes, we can deduce that Member States are in contact with 14 to 18 other countries. Within this network of collaboration, we find a considerable number of exchange relations, and the number of links between sending and receiving administrations even increased between 2008 and 2016 (from 461 to 584). The density of the networks changes somewhat in the period of analysis, with the highest coefficient in 2011, but generally we can detect continuity, even growth.

The findings are even more impressive when looking at the average number of Dublin requests exchanged, as this number increases steadily from 659 in 2008 to more than 2,100 since 2013 - with a disproportional increase in the number of cases in 2016 as a consequence of the increased immigration of refugees in 
2015. With this increased intensity, the network moved closer together: the statistical tools of network analysis have identified three subgroups in the years between 2008 and 2011, which have disappeared or merged into one comprehensive network since 2012. That is, while cooperation disaggregated into separate groups that were only loosely coupled, in 2012 the network became more integrated in terms of mutual relations of exchanges. However, as we will see later on, this does not mean that exchanges are evenly distributed across Member States. The network exhibits a clear core-periphery structure with a very asymmetric distribution of workloads, as shown in Figure 8.1. Towards 2016, the inequalities increased dramatically, because Dublin requests addressing Italy became focal. ${ }^{9}$

The picture does not change substantially when we move from Dublin requests to factual transfers, as shown in Figure 8.2 and Table 8.2. The most notable change relates to total numbers. While national administrations have exchanged Dublin requests in 1,537 cases - on average - with other countries in 2012, only one out of five cases led to a transfer (i.e. 295 cases on average) in the same year. In 2015 , the number of requests increased to 2,486 cases, with only 330 transfers on average. However, the internal structure of the network is still very similar, as shown in Figure 8.2. For 2016, it is remarkable to see that the number of requests

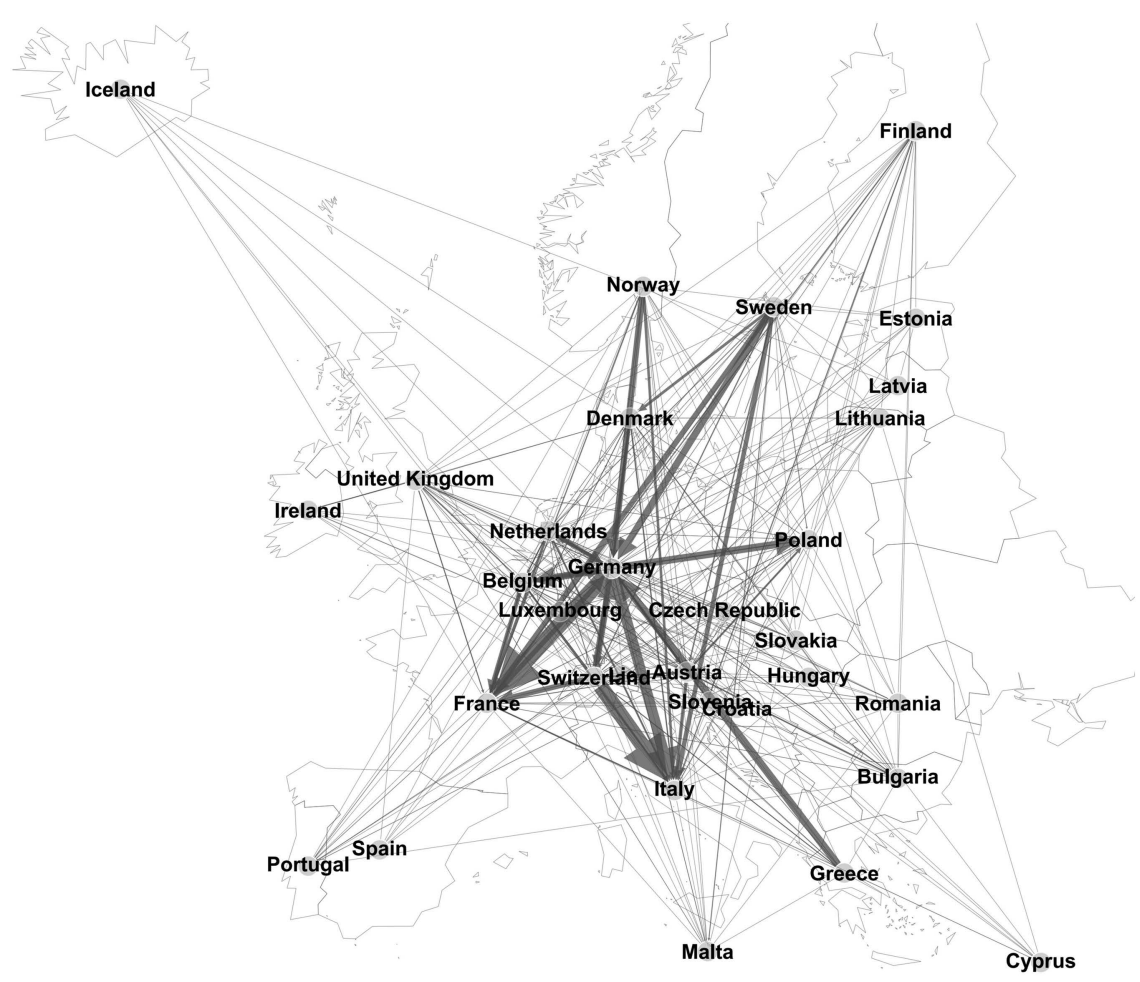

Figure 8.2 Dublin transfers between EU Member States in 2015 (social network analysis) 
Table 8.2 Dublin transfers: network structure 2008-2016

\begin{tabular}{lccccccccc}
\hline Year & 2008 & 2009 & 2010 & 2011 & 2012 & 2013 & 2014 & 2015 & 2016 \\
\hline $\begin{array}{l}\text { Number of edges } \\
\text { Average degree }\end{array}$ & 272 & 348 & 312 & 359 & 346 & 340 & 316 & 333 & 313 \\
$\quad$ (countries) & 8.5 & 10.9 & 9.7 & 11.2 & 10.8 & 10.6 & 9.9 & 10.4 & 9.8 \\
$\begin{array}{c}\text { Average weighted } \\
\text { degree (transfers) }\end{array}$ & 189 & 326.5 & 280.8 & 290.7 & 294.9 & 453.8 & 371.9 & 330.4 & 368.5 \\
$\begin{array}{c}\text { Graph density } \\
\begin{array}{c}\text { Connected } \\
\text { components }\end{array}\end{array}$ & 0.27 & 0.35 & 0.32 & 0.36 & 0.35 & 0.34 & 0.32 & 0.34 & 0.32 \\
\hline
\end{tabular}

Source: Eurostat, own calculations.

increased dramatically to an unprecedented 5,832 cases. But this has only had limited effects on the number of factual transfers, as they remain below the number reached in 2013 .

As the number of transfers is lower, the network is less dense in its structure of cooperation. This is indicated by the average number of countries that cooperated, and by the overall density of the network. Yet in terms of time, the working relations with other Member States tended to remain stable. National authorities maintained regular contacts with around 9 to 11 other Member States. Also, the average number of transfers per country fluctuated between 272 and 359 between 2008 and 2016, without indicating a clear pattern of growth. Only with regard to components was there a change across time: While the network tended to disaggregate into three subgroups at the beginning of the reporting period, we see that the groups were absorbed into the overall network, probably by a more even distribution of contacts across the field. Here again, Italy became the centre of attention when looking at the intensity of transfers (see arrows in Figure 8.2), followed by Poland.

This final observation raises questions about the internal patterns of collaboration within the European administrative field. For this purpose, we need to move a step further and look at individual countries. So far, the graphs and tables have shown that the European field is quite strongly integrated, meaning that there is a rather low tendency to cluster into distinct subgroups. Tables 8.1 and 8.2 indicate that the overall network with regard to Dublin requests has only consisted of one major component since 2013, and the same applies for transfers.

These observations do not necessarily exclude other forms of spatial clustering. Figures 8.1 and 8.2 suggest that the administrative field is patterned along a concentric structure, moving from a core area with intense exchanges of Dublin requests, and a rather weakly interrelated periphery. This impression is corroborated by Figure 8.3, which summarises the cooperation patterns of each Dublin Member State. For this purpose, we have looked at Dublin requests and the number of contacts each public administration maintains to other Member States. We have taken in-coming and out-going contacts into consideration (i.e. measures of in-degree and out-degree). As we are interested in the overall structure of the 


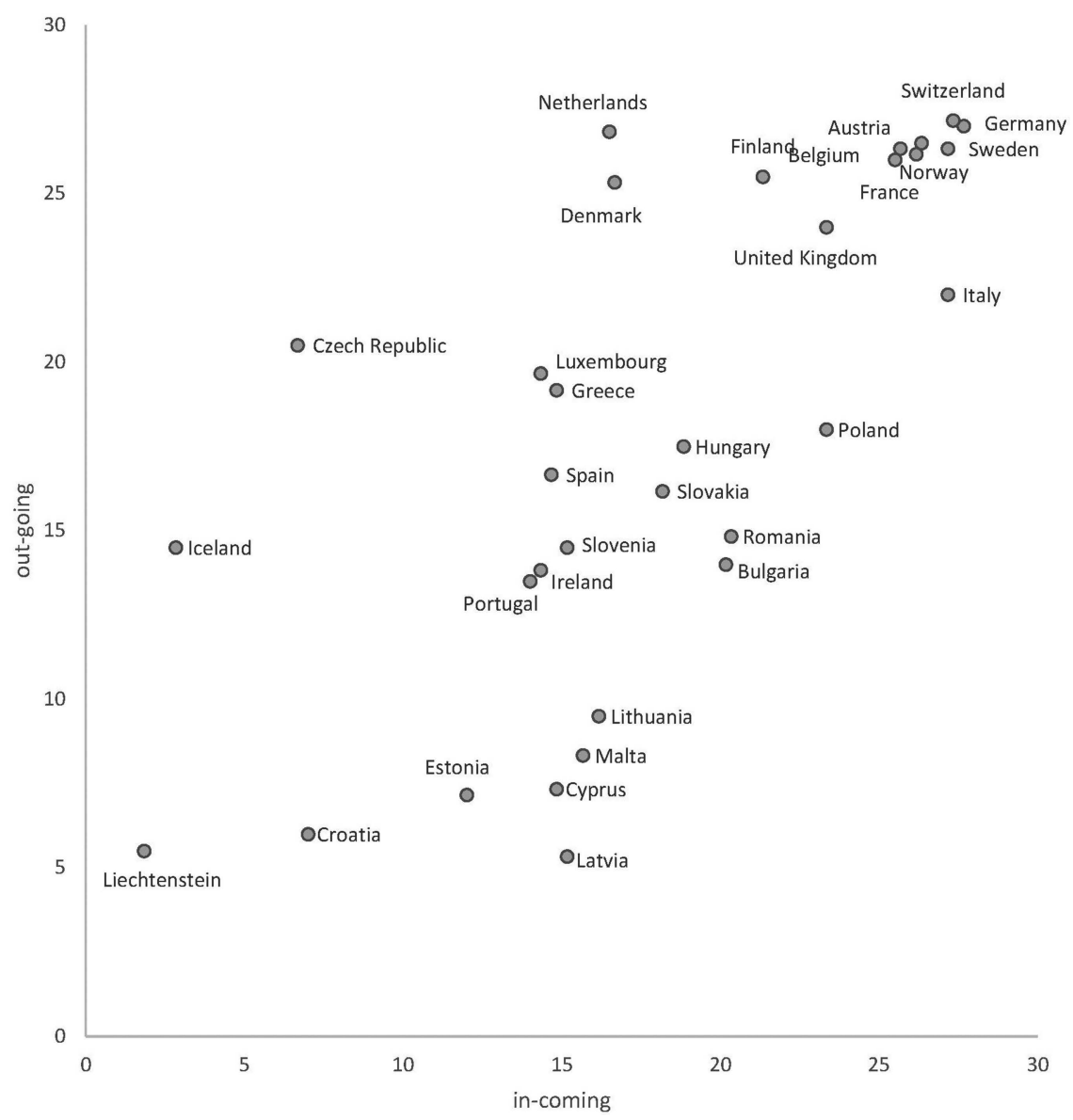

Figure 8.3 Work relations among countries (Dublin requests 2010-2015; means)

network across time, we have calculated the mean number of in-coming and outgoing contacts for the period of 2010 and 2015.

The findings show that the Dublin network has indeed a concentric structure. On the top-right side, we find those countries with the most extended number of contacts to other Member States. This group consists of the EU-6 countries (Belgium, the Netherlands, France, Germany and Italy), except Luxembourg. Other core Western and Northern European countries join this group, in particular the Scandinavian countries, Austria and the UK. Southern and Eastern European Member States are much more disconnected, and this is particularly true for South-eastern countries, as well as those in the Baltic region.

These findings unveil the internal structure of working relations within the administrative Dublin network, but they disregard the intensity of these exchanges. 
Tables 8.1 and 8.2 indicated that the workload was quite substantial, and hence, we might assume that the division of labour was not an even one. On the contrary, it is to be expected that numbers would disclose considerable imbalance and inequality. Some countries should be exposed to much more intense exchange relations than others. In order to portray these imbalances and inequalities, it is necessary to differentiate Dublin-based working relations along the direction of the requests and transfers. Indeed, for the various administrations it made a big difference whether they sent requests out, asking other countries to take responsibility for processing asylum-procedures, or whether they received these kinds of requests and were asked to take over. Even more consequential are the Dublin transfers, and thus the question becomes even more relevant to see which countries are on the receiving and sending side. Figure 8.1 has already demonstrated that almost all countries are on both sides, i.e. they received and sent Dublin requests. This is less obvious for transfers (Figure 8.2), but the numbers provided by Eurostat on Dublin requests show that most countries were indeed placed at the receiving and sending side. Cyprus and Malta did not issue Dublin transfers to other countries in 2012, while the Scandinavian countries (Denmark, Finland, Norway, Sweden and Iceland) did not receive transfers. At the same time, Italy was not only exposed to large numbers of incoming refugees from the Mediterranean Sea, but also to large numbers of incoming Dublin requests and transfers.

To visualise these uneven patterns of cooperation, we have inserted them into graphs in Figure 8.4. These two plots give an overview of the average number of Dublin requests and transfers per country in 2015. The findings show that Italy was primarily involved in the European field of administrative collaboration on the receiving side, because it received 25,000 requests and more than 2,000 transfers, overall. On the sending side, we can name Germany, Switzerland, Sweden and France as well as Belgium, Austria, Norway, Denmark and the UK. These countries did receive Dublin requests, and a few of them received a considerable number of transfers, in particular Germany. Overall, Dublin collaborations exhibited a distinctly uneven structure, which was to be expected, knowing the challenges the immigration routes imposed on Italy, and the particular burden the Dublin system placed on this country, consequently. It underscores inequalities and cleavages in the European field of administrative cooperation.

The imbalance between requests and transfers hints at potential limitations of the effectiveness of the Dublin system. In 2016, the ratio between factual transfers and requests was only $14.7 \%$, i.e., only one in every six cases was actually transferred to another Member State. This figure was higher in 2010 (i.e. 20.7\%), but not impressively higher, thus showing that factual cooperation between national administrations is limited and troublesome.

All these problems seem to be particularly relevant in the case of Italy. In fact, Italy seems to provide an illustrative example for the imbalance and implicit conflicts within the European administrative field. As Table 8.3 depicts, the numbers for factual transfers - the 'effectiveness' - differs from country to country remarkably in the case of Italy. So, the inherent asymmetries of the arrangement of the administrative cooperation in the case of Italy evidently affects the balance of services of many Member States. 


\section{Requests}

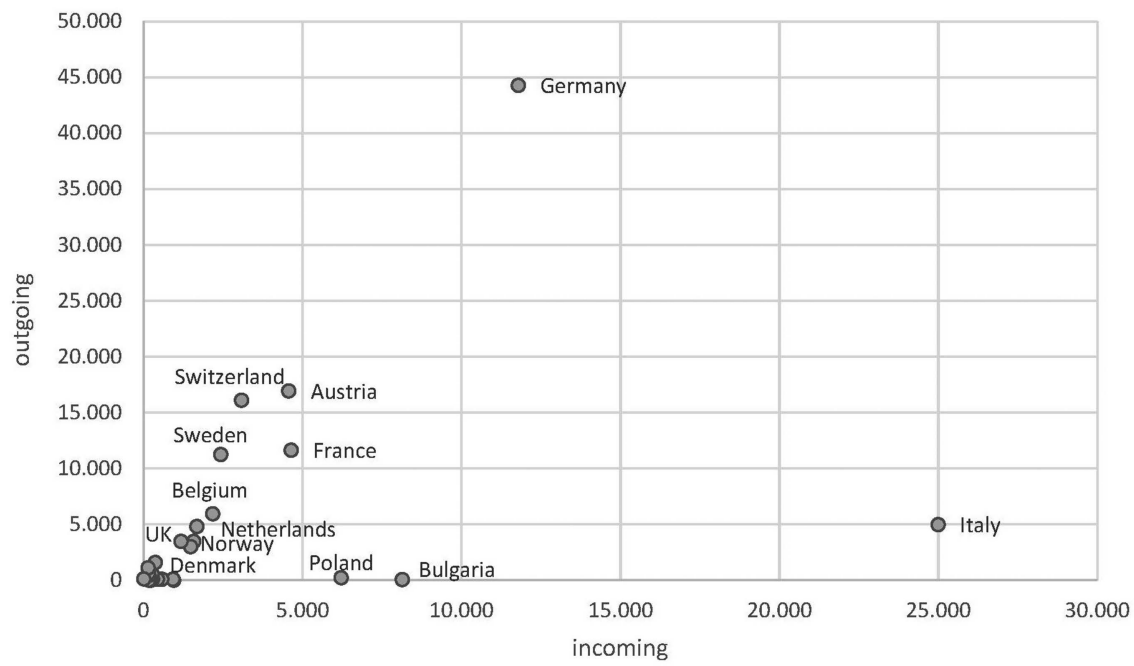

Transfers

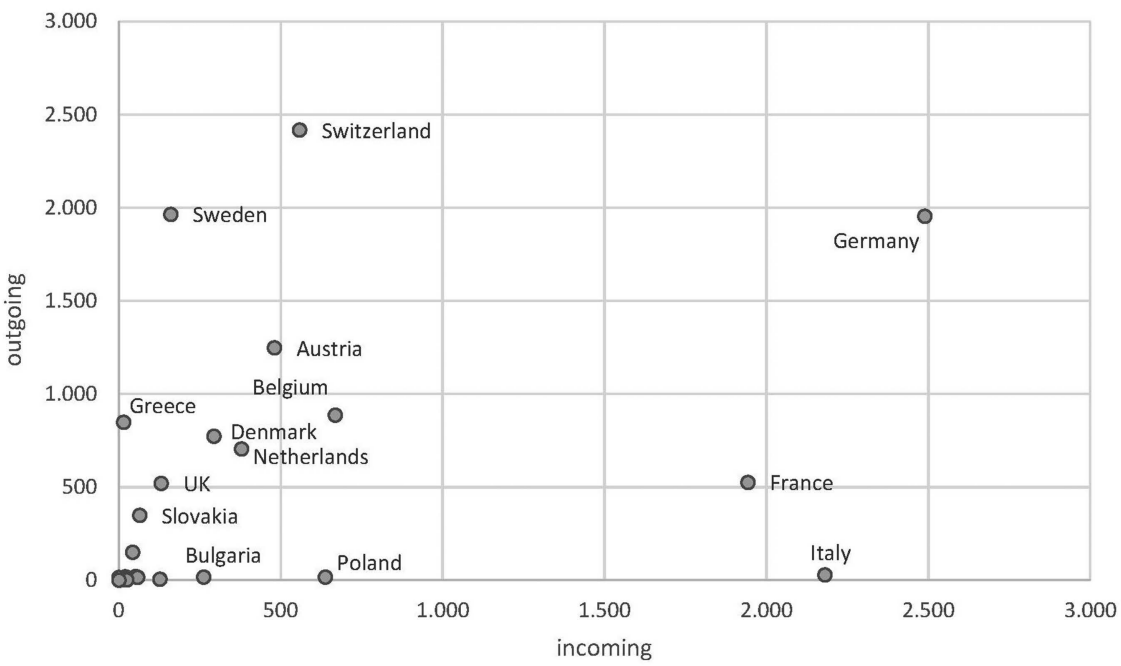

Figure 8.4 The number of Dublin requests/transfers per country (2015)

Note: Except those with missing data, all EU+ countries are included (i.e. in total 26 cases). Member States with fewer than 1,000 incoming Dublin requests without country label: top graph; countries with fewer than 100 outgoing Dublin transfers (plus Italy, Poland and Bulgaria) without data labels: bottom graph. The number of incoming transfers for Sweden (January-10 October) was taken from the AIDA country report 2015 (www.asylumineurope.org/sites/default/files/report-download/aida_se _ update.iii_.pdf). 
Table 8.3 Incoming Dublin requests to Italy from selected Member States, decisions accepted and factual transfers to Italy 2015 (number of incoming requests above 100)

\begin{tabular}{lcccc}
\hline & $\begin{array}{l}\text { Incoming } \\
\text { Requests }\end{array}$ & $\begin{array}{l}\text { Decision } \\
\text { Accepted }\end{array}$ & Transfers & $\begin{array}{l}\text { Transfer Quota (Incoming } \\
\text { Transfers/Decision } \\
\text { Accepted) }\end{array}$ \\
\hline Switzerland & 8,713 & 3,741 & 737 & $20 \%$ \\
Germany & 8,492 & 6,387 & 519 & $8 \%$ \\
France & 2,202 & 1,972 & 69 & $3 \%$ \\
Sweden & 1,489 & 1,103 & 219 & $20 \%$ \\
Austria & 1,355 & 956 & 162 & $17 \%$ \\
Belgium & 776 & 569 & 99 & $17 \%$ \\
Norway & 713 & 264 & 125 & $47 \%$ \\
The Netherlands & 487 & 380 & 90 & $24 \%$ \\
Denmark & 314 & 220 & 65 & $30 \%$ \\
Finland & 257 & 185 & 57 & $31 \%$ \\
\hline
\end{tabular}

Source: Eurostat, own calculations.

A series of factors seem to be responsible for this. First, we can assume that administrative structures are relevant, such as the size of the administration, the years of 'administrative experience' within the EU and the Dublin system, the similarities of legal and administrative structures, the length and intensity of administration collaboration between national agencies. Other causes need to be added, e.g. the number of cases, the attempts of asylum applicants to contest or withdraw themselves from a transfer, the suspension of transfers to certain Member States due to legal litigation and court decisions, and disagreements between 'bargains' among agencies regarding the concrete tasks and issues within the core of the Dublin operating system (Jurado et al., 2016: 59-62). Finally, reasons immediately tied to the practices of administrative cooperation directly impact on the effectiveness. In particular, it is highlighted in documents and studies that public authorities seem to play for time. In fact, the Dublin Regulations define clear deadlines until a final agreement about the responsibility for a case has been settled. Once this deadline has been transcended, the requesting Member State becomes 'responsible by default'10 (Jurado et al., 2016: 59). This means that the work performance of a single Dublin Unit directly affects the caseload of other European asylum agencies. Additionally, we have already mentioned that cooperation at the 'street-level' is also constrained by diverging interpretations concerning the conditions and prerequisites - especially regarding the medical condition of the person to be transferred (Jurado et al., 2016: 60-61) - thus endangering the exact coordinates of a transfer (e.g. regarding a suitable date/hour for the transfers).

\subsection{Discussion and conclusion}

Public debate in the mass media and political conflicts between Member States since 2015 have shown that the Common European Asylum System is in crisis. Inner EU struggles concerning the distribution of forced migrants are currently 
the strongest articulation of these internal conflicts. In this time of crisis, Member States have made disputable decisions that have put the continuity of the CEAS at risk. Even a fundamental transformation of the Dublin system was part of this discourse, but this option was discarded in the proposals made by the EU Commission in May 2016 (European Commission, 2016, 2017a).

To this day, the rationale of the Dublin system has widely remained unaffected by the dramatic challenges and the crisis-driven conflicts within the EU institutions. Officially, the Dublin procedure shall continue as a 'cornerstone' of the CEAS (European Commission, 2016: 4). One of the main reasons for this continuity seems to be a political priority: The EU is deeply committed to the maintenance of the Schengen area. Schengen is of constitutive importance for the European project regarding its symbolic and economic value (e.g. free movement of persons), and thus seems to leave no alternative to the Dublin mechanism and the allocation of responsibility for persons 'illegally' entering, staying or moving around in the territory of the EU+ countries. The dictum that 'no Dublin means no Schengen' is not only responsible for the continuity of the Dublin system, it has also led to a partial extension and adjustment of competences within it. This is the case, for instance, with respect to the support Italy and Greece have received with regard to the registration, allocation and distribution of asylum applicants by employees of other Member States agencies, also in the Dublin procedure provided for the administrative handling of Dublin cases in Italy (EASO, 2016b, 2016c).

Beyond doubt, the importance of the Dublin system should not be overrated when looking at the administrative practices of the asylum agencies of the Member States. As mentioned in the introduction of this paper, Dublin cases make up only a small fraction of all asylum applications. Furthermore, the allocation of responsibility via Dublin is only one element within the long and complex procedure of the handling of an asylum application. Microsociological and ethnographic studies have shown that the decisive elements of the procedure (evidence assessment and decision making) are obeying country-specific pre-settings, requirements and practices (Lahusen and Schneider, 2017; Parusel, 2015; Toshkov and Haan, 2013) and therefore are only marginally affected by the harmonisation efforts made by the EU. However, the Dublin system influences the administrative work of Member State agencies at least in an indirect manner, because it inserts these agencies into a transnational division of administrative labour.

The analysis of the practical cooperation under the umbrella of the Dublin system has generated two findings that help to better understand the European administrative field in its formation, internal structure and functioning. First, empirical evidence presented in this chapter has shown that the Dublin system exhibits a remarkable continuity and stability - at least on the level of administrative action. Our findings highlight that it has established a stable transnational administrative field over the years based on procedures and practices concerning the allocation of responsibility. States' agencies dealing with asylum applicants have become involved more and more in this division of labour so that the general exchange of information and the number of transfer requests has increased across time. Second, our analyses have identified remarkable imbalances and inequalities. Especially 
in the core area of the 'old' EU Member States, an intensive exchange of requests has become commonplace, while transnational cooperation has tended to thin out towards the periphery. Italy has maintained a focal position in this network of cooperation, due to its exposed position when considering migration routes and the high share of Dublin requests it receives. The effectivity of the Dublin system is rather low, thus mirroring internal conflicts and problem-shifting efforts.

Two central conclusions arise on the basis of our empirical findings. First, the analysis of Dublin data attests that Member States are indeed part of a European administrative field as conceptualised in section 8.2 of our chapter. This field reproduces itself by means of regular contacts and exchanges impelled and facilitated by the formalised, standardised and digitalised procedures established and initiated by the Dublin Regulations. This mode of horizontal Europeanisation by norms has established the only genuine horizontal 'European' administrative procedure in the field of asylum administration. Additionally, we can expect that a cross-national discourse arena of bureaucratic information exchange and deliberation is in place, which helps to stabilise administrative cooperation and mitigate potential challenges and conflicts arousing from unsettled imbalances and inequalities in 'burden-sharing'. Overall, the steadfastness of cross-national exchanges is considerable and attests to a proper bureaucratic field in operation with its deficiencies and contradictions - within a political environment marked by substantial conflict and crisis.

Second, the continuity and stability of the Dublin system should not be taken as proof that political tensions and conflicts surrounding the European asylum policies could be solved by a further bureaucratisation. The EU-enforced Dublin Regulations and the transnational work context it has established by norms of standardisation is a revealing example of 'cooptition' (competitive cooperation) in the European field of asylum administration. The Dublin system was and is always contested by symbolic struggles within the field of asylum policies, and its implications are reflected and sedimented in the daily administrative operating of the Dublin system. It is true that the existing Dublin system was not established to solve an unfair 'burden-sharing', but just to coordinate administrative responsibilities. However, the latent contentiousness is ever present. The low effectivity of the Dublin system, which lurks behind the low rate of transfers compared to the number of requests, clearly illustrates these imbalances, conflicts and problems. The low effectivity of the Italian administration in dealing with Dublin requests and transfers makes clear that it is hardly capable of dealing with the position allocated to it within the uneven division of administrative labour. Low transfer rates and the deficient registration performance of some countries on the Southern, Eastern and South-eastern periphery of the Dublin system seem to indicate counter strategies enacted by these countries to shift part of the problem back to an unfavourable system.

Overall, we see that the Dublin system reproduces a highly asymmetric division of labour with internal cleavages and conflict potential. The Dublin system offers only limited possibilities to compensate and even diminish these asymmetries and tensions. Support measures have been introduced (e.g. sending personnel from 
single asylum agencies and EASO to countries with high caseloads), but they only substantiate this reality. The EU and its Member States is thus holding on to the Dublin system, in spite of the uneven 'burdens' it imposes on national administrations, and in spite of the considerable risks and privations this 'asylum lottery' (AIDA, 2017) imposes on applicants and their families (e.g. concerning family reunification, long waiting period for an examination and uncertainties about the responsible Member States). The Dublin system's future is dependent on a true political solution committed to the idea of equally weighted responsibility sharing and dedicated cooperation among Member States.

\section{Notes}

1 Differences exist in the organisational structure of the Dublin Units in the respective Member States. According to a 2016 study, most Member States have installed specialised Dublin Units, some have not. Moreover, tasks and responsibilities vary per Member State (concerning screening, conducting Dublin interviews, arranging and implementing transfers) and the number of specialised case officers differs enormously from 0-5 (e.g. Croatia), 11-20 (e.g. Italy), 40-60 (e.g. Switzerland) up to 60-80 (e.g. Sweden) in 2016 (Jurado et al., 2016: 3-7). In 2017, the staff in the respective German agency working on Dublin numbered more than 300 (Deutscher Bundestag, 2017: 23).

2 A Dublin request is an official administrative act of the respective unit or case worker asking another Member State unit via DubliNet (electronic communication tool) to take responsibility for an applicant due to the fact that the Member State being addressed is responsible with regard to criteria formulated in the Dublin Regulation 604/2013 (European Parliament and European Council, 2013). A transfer is the 'numbers of transfers to which the decisions taken in response to the requests' lead (see Eurostat; https://bit.ly/2x0gRdw, accessed on 19 June 2018).

3 The ETC also includes a Dublin Regulation Module that is used to train Member State staff on operational aspects and tasks of the Dublin Regulations (EASO, 2017b: 18).

4 See European Commission (2018) for different types and forms of support (financial, technical, staff) and 'solidarity' or 'burden-sharing' mechanisms in the framework of the European Agenda on Migration.

5 An accusation mainly brought up in the frame of the EU Relocation programme. See Reports on Relocation and Resettlement published by the European Commission (https://bit.ly/2hbrJz8, accessed on 27 February 2018).

6 A very illustrative example is the engagement of Polish and Slovakian state officials supporting the Italian authorities in conducting the EU Relocation Scheme; two countries that on the highest political level are strictly opposing any relocation of eligible persons to their countries in this framework, but supporting its functioning in principle on the administrative operational level (EASO, 2018).

7 We wish to thank Elisabeth Kisseler for her support with respect to data retrieval and network analysis.

8 We have used statistical data provided by Eurostat on the operating of the Dublin system from 2008-2016 available on https://bit.ly/2NCAJNr, accessed 15 February 2018. For information on the methodology applied by Eurostat see https://bit.ly/2x0gRdw.

9 Since 2011, transfers of asylum seekers from Member States to Greece under the Dublin Regulations had been suspended, following rulings of the European Court of Human Rights and the CJEU (e.g. M.S.S. v. Belgium \& Greece) (Georgopoulou et al., 2018: 60).

10 The time limit could be extended to up to 18 months under certain prerequisites (imprisonment, abscondence of the applicant) to ease and speed up the transfer procedure; several Member States have agreed on bilateral arrangements (Jurado et al., 2016: 59, 62). 


\section{References}

AIDA - Asylum Information Database (2015) Asylum statistics in the European Union: $A$ need for numbers. Brussels. Available at: https://bit.ly/2N0XsDa (accessed 29 August 2018).

AIDA - Asylum Information Database (2017) Asylum statistics 2016: Sharper inequalities and persisting asylum lottery. Brussels. Available at: https://bit.ly/2QkkAe2 (accessed 26 August 2018).

Amelung N (2017) Politikinstrumente in der europäischen Asylpolitik: Zur Rolle von Experten und Expertise. In: Lahusen $\mathrm{C}$ and Schneider S (eds) Asyl verwalten. Bielefeld: Transcript Verlag, pp. 27-54.

Angenendt S and Parkes R (2010) Neuer Impuls für die EU-Asylpolitik? Möglichkeiten und Grenzen des neuen Unterstützungsbüros für Asylfragen. SWP Aktuell 60: 1-4 (accessed 17 June 2018).

Bast J (2007) Transnationale Verwaltung des europäischen Migrationsraums. Der Staat Zeitschrift für Staatslehre und Verfassungsgeschichte, deutsches und europäisches öffentliches Recht 46: 1-32.

Baumgartner P, Dimitriadi A, Wagner M, et al. (2016) Implementation of the common European asylum system: Study for the LIBE committee. Brussels. Available at: https:// bit.ly/2QhM2ZN (accessed 23 July 2018).

Bourdieu P (1987) Sozialer Sinn: Kritik der theoretischen Vernunft. Frankfurt am Main: Suhrkamp.

Bourdieu P (1991) Die Intellektuellen und die Macht. Hamburg: VSA-Verlag.

Bourdieu P (1997) Der Tote packt den Lebenden. Hamburg: VSA-Verlag.

Bourdieu P (1998) Praktische Vernunft: Zur Theorie des Handelns. Frankfurt am Main: Suhrkamp.

Chetail V, Bruycker PD and Maiani F (2016) Reforming the common European asylum system: The new European refugee law. Leiden, Boston: Brill Nijhoff.

Council of the European Union (2016a) Draft council conclusions on convergence in asylum decision practices. Brussels. Available at: https://bit.ly/2NCgX4F (accessed 14 May 2018).

Council of the European Union (2016b) Progress report on the Dublin regulation, the reception conditions directive, the qualification regulation, the asylum procedure regulation, the reception conditions directive, the qualification regulation and the resettlement framework regulation. Justice and Home Affairs Council Meeting 08-09/12/2016, Brussels. Available at: https://bit.ly/2O5i49E (accessed 23 June 2018).

Deutscher Bundestag (2017) Antwort der Bundesregierung auf die Kleine Anfrage der Abgeordneten Ulla Jelpke, Frank Tempel, Sevim Dağdelen, weiterer Abgeordneter und der Fraktion DIE LINKE. - drucksache 18/13190 - : Ergänzende informationen zur Asylstatistik für das zweite Quartal 2017 - Schwerpunktfragen zum Dublin-Verfahren. Berlin: Deutscher Bundestag.

EASO - European Asylum Support Office (2016a) Annual report on the situation of asylum in the European Union 2015. Valletta. Available at: https://bit.ly/29tJKSB (accessed 22 April 2018).

EASO - European Asylum Support Office (2016b) EASO operating plan to Italy. Valetta. Available at: https://bit.ly/2k5ZToe (accessed 18 December 2017).

EASO - European Asylum Support Office (2016c) EASO special operating plan to Greece. Valletta. Available at: https://bit.ly/2h1M2dF (accessed 22 May 2018).

EASO - European Asylum Support Office (2017a) Annual report on the situation of asylum in the European Union 2016. Valletta. Available at: https://bit.ly/2tPq48p (accessed 22 October 2017). 
EASO - European Asylum Support Office (2017b) EASO training curriculum. Valletta. Available at: www.easo.europa.eu/training (accessed 11 November 2017).

EASO - European Asylum Support Office (2018) EASO's support in Italy. Email. Unpublished. Rome.

ECRE (2016a) The road out of Dublin: Reform of the Dublin regulation. Brussels. Available at: https://bit.ly/2tnoaZi (accessed 23 August 2017).

ECRE (2016b) ECRE comments on the commission proposal for a Dublin IV regulation: $\operatorname{COM}(2016)$ 270. Brussels. Available at: https://bit.ly/2q9vDvJ (accessed 14 November 2017).

ECRE (2018) Making asylum numbers count. Brussels. Available at: https://bit.ly/2x1w3WW (accessed 13 November 2018).

European Commission (2015) Report from the commission to the European parliament and the council: On the implementation of regulation (EC) No 862/2007 on community statistics on migration and international protection. Text with EEA relevance. Brussels. Available at: https://bit.ly/2MZ4BDT (accessed 2 December 2017).

European Commission (2016) Proposal for a regulation of the European parliament and of the council establishing the criteria and mechanisms for determining the member state responsible for examining an application for international protection lodged in one of the member states by a third-country national or a stateless person (recast). Brussels: European Commission.

European Commission (2017a) A European agenda on migration: State of play: March 2017. Brussels. Available at: https://bit.ly/2NwZ2Mz (accessed 22 May 2018).

European Commission (2017b) Communication from the commission to the European parliament, the council, the European economic and social committee and the committee of the regions: On the delivery of the European agenda on migration. Brussels. Available at: https://bit.ly/2QbRbCL (accessed 7 June 2018).

European Commission (2018) Communication from the commission to the European parliament, the European council and the council: Progress report on the Implementation of the European agenda on migration. Brussels. Available at: https://bit.ly/2MtLpgE (accessed 3 June 2018).

European Parliament and European Council (2013) Regulation (EU) No 604/2013 of the European parliament and of the council of 26 June 2013 establishing the criteria and mechanisms for determining the member state responsible for examining an application for international protection lodged in one of the member states by a third-country national or a stateless person (recast). Brussels: European Commission.

Featherstone K and Radaelli CM (eds) (2003) The politics of Europeanization. Oxford: Oxford University Press.

Fratzke S (2015) Not adding up: The fading promise of Europe's Dublin system. EU Asylum: Towards 2020 Project. Brussels. Available at: https://bit.ly/2x1VRSH (accessed 9 May 2017).

Georgopoulou A, Drakopoulou A, Fragkos V, et al. (2018) Country report: Greece: 2017 update. Available at: https://bit.ly/2G5vKP2 (accessed 16 June 2018).

Hruschka C (2016) Dublin is dead! Long live Dublin! The 4 May 2016 proposal of the European commission. Available at: https://bit.ly/2i3u7Zh (accessed 23 November 2016).

Jurado E, Beirens H, Maas S, et al. (2016) Evaluation of the implementation of the Dublin III regulation: Final report. DG Migration and Home Affairs. Brussels. Available at: https://bit.ly/2s5obA1 (accessed 18 March 2017).

Kasparek B and Tsianos VS (2015) Back to the future: Blair-Schily reloaded. Movements. Journal for Critical Migration and Border Regime Studies 1(1): 1-25. 


\section{Christian Lahusen and Marius Wacker}

Lahusen C (2016) Auf dem Weg zu einem europäischen Verwaltungsfeld? Zur Soziologie der Bürokratisierung Europas am Beispiel des Gemeinsamen Europäischen Asylsystems. Berliner Journal für Soziologie 26(1): 109-133.

Lahusen C and Schneider S (eds) (2017) Asyl verwalten. Bielefeld: Transcript Verlag.

Lorenz D (2015) Verhandlungen um Dublin III: Entwicklungslinien und Widersprüche der europäischen Asylpolitik. Vorgänge - Zeitschrift für Bürgerrechte und Gesellschaftspolitik 54: 25-49.

Maas S, Jurado E, Capdevila M, et al. (2015) Evaluation of the Dublin III regulation: Final report. DG Migration and Home Affairs. Brussels. Available at: https://bit.ly/2Qkt5ps (accessed 3 November 2017).

Maiani F (2016) The reform of the Dublin III regulation: Study for the LIBE committee. Brussels. Available at: https://bit.ly/2O1LWUr (accessed 11 April 2017).

Parusel B (2015) Solidarity and fairness in the common European asylum system - failure or progress? Migration Letters 12: 124-136.

Schneider S and Nieswandt C (2018) EASO - support office or asylum authority? Boundary disputes in the European field of asylum administration. Österreichische Zeitschrift für Soziologie 43(S1): 13-35.

Toshkov D and Haan L de (2013) The Europeanization of asylum policy: An assessment of the EU impact on asylum applications and recognitions rates. Journal of European Public Policy 20(5): 661-683.

Trauner F (2016) Asylum policy: The EU's 'crises' and the looming policy regime failure. Journal of European Integration 38(3): 311-325.

Wagner M (2018) What remains 'common' in the "European Asylum System" if Dublin fails? Available at: https://bit.ly/2MjYUey (accessed 18 July 2018). 